\title{
Municipal Bond Boom in Hungary: Focusing on the Analysis of Local Financial Management ${ }^{\#}$
}

\author{
Gábor KOVÁCS*
}

\section{Introduction and historical overview of local borrowing}

Following the 1990s, after the termination of the economic transition the Hungarian local government system had to meet new challenges and expectations. Due to the decentralization process local governments' revenues decreased significantly in the last two decades in real value, while the level and scope of services provided did not decrease at the same time. In the first place local governments, which are short of resources, have had to perform probably one of their most important tasks: to develop their resource absorption and fund-raising capacity, which would ensure the necessary financial tools execute development. The enhancement of the resource-deployment capacity of the local authority sector is a fundamental condition for ensuring the necessary development resources at the local level. The extension of the capital absorption capacity at sub-national level is of high importance from the EU's support opportunities' aspect also.

One of the diverse methods of using outside resources is the usage of loan resources, among which resource acquisition via local government bond issuance should be listed as well. The timeliness of my research is primarily proved by the fact that compared to the mid-2000s substantial changes have occurred in the scale of indebtedness of Hungarian local governments. After the early and temporary "bond boom" in the middle of 1990's, the size of indebtedness started to increase considerably, first

\footnotetext{
\# Research published in this paper was supported by the Regional Operational Program (ROP) 3.1.1 of National Development Agency of Hungary and by the Government Center for Public Administration and Human Resource Services.

Dr. Gábor Kovács, Ph.D. - Senior Lecturer; Department of Business Analysis, Kautz Gyula Faculty of Economics, Széchenyi István University, Egyetem tér 1, 9022 Győr, Hungary; <kovacsg@sze.hu>.
} 
in 2002. At the end of 2009 the size of financial obligations deriving from local borrowing amounted more than $4 \%$ of GDP.

The extremely high volume of local government debt started in 2006, caused primarily by the issuance of local government bonds. While up to 8 billion HUF worth of bonds were issued in 2006, the bond issuance value in 2007 nearly reached the HUF 200 billion and in 2008 exceeded this amount. Consequently the portfolio of bonds issued in HUF reached 50 billion HUF, while the value of those denominated in foreign currencies increased above 350 billion HUF. According to the report made by the Public Expenditure Survey Committee, $20 \%$ of municipalities issued bonds in 2007 (among local governments that were audited by the Committee).

Fig. 1: Liabilities (municipal bonds, short and long term loans) of Hungarian local governments in the percentage of GDP and local governments' revenues (1995 - 2009)

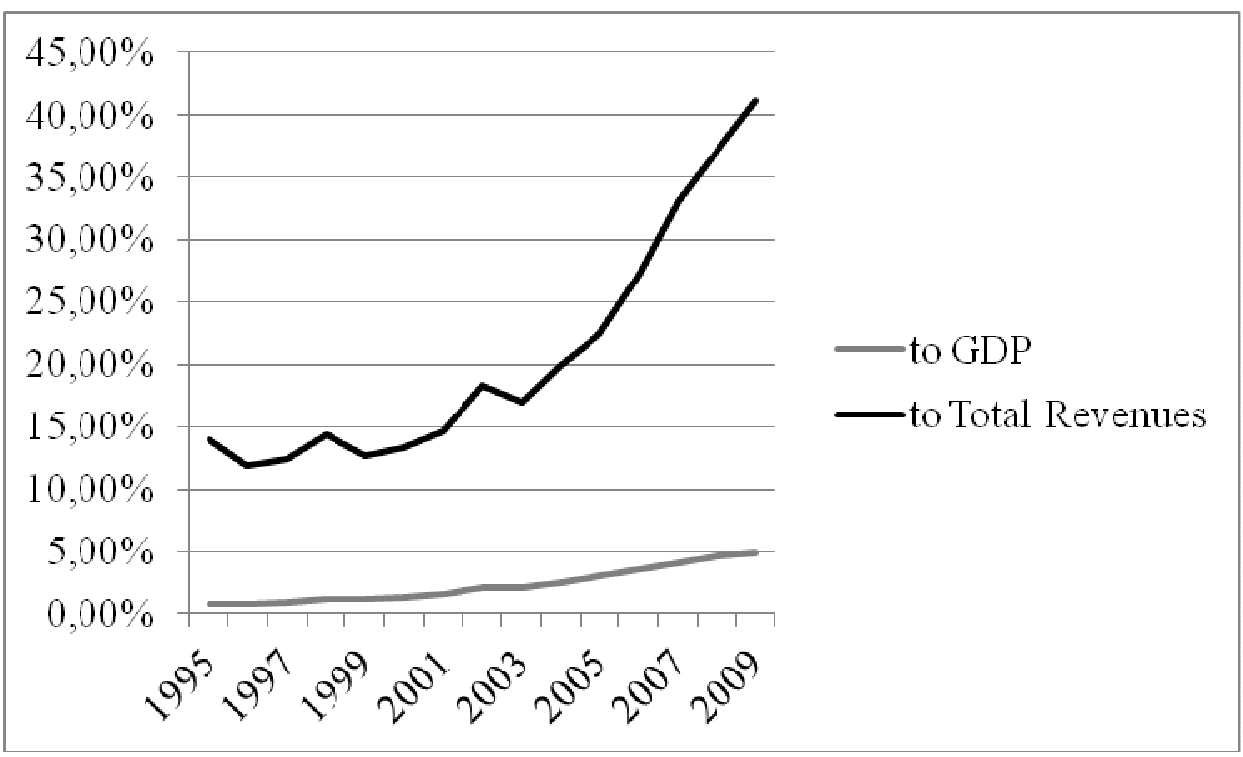

Source: Hungarian National Bank (2011).

The paper is aimed at examining factors that might have been behind indebtedness, and tries to separate the effect of internal and external variables. As internal factors I mean first of all the quality of local financial management, the professional knowledge and the attitude of local governments' executives towards bond-financing. In the 1990s local governments were reluctant to use loan resources because of the over- 
indebtedness of the previous socialism regime, and they considered indebtedness as a sign of weakness.

As bond financing was in Hungary a fairly new, not widely known and complex way of fund-raising for the local sector at the beginning of the first decade of $20^{\text {th }}$ century only the most innovative local governments with highly skilled financial management were not afraid to use it. Can the increasing indebtedness be considered to have been accelerated by the improvement in quality of local financial management and by the positive change in local governments' attitude towards loan financing? Or have only external factors such as legislation, the central subsidy policy, and the macro-economical situation of Hungary played the major role?

\section{Fig. 2: The formation of local governments' borrowing between} 2000 and 2008

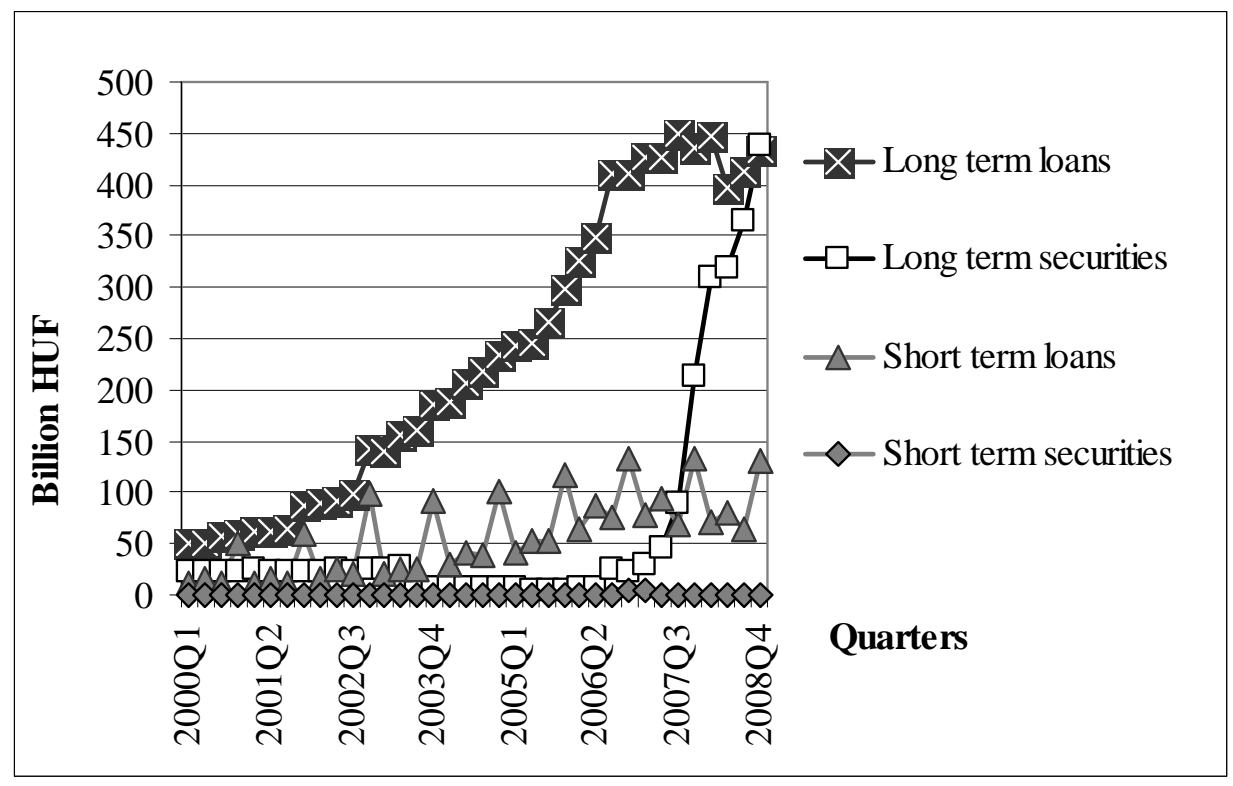

Source: Hungarian National Bank (2011).

In this paper I attempt to analyse the general level of Hungarian local governments' professional knowledge and their attitude towards bond financing. In addition, my research tries to develop factors that are not necessarily rational but sometimes subjective. The data set being studied includes a representative sample of 308 Hungarian local governments. After analysing the results of the survey I make a conclusion whether 
internal factors might have been the drivers of the bond boom or external factors have prevailed.

\section{Theoretical framework for the analysis}

In order being able to analyse the level and quality of theoretical knowledge of local governments firstly the most important economic relationships and correlations of local borrowing (and inside that bondfinancing) must be identified and formulated. Accordingly, in what follows I try to define the general statements of the method for loan resource application and issuing municipal bonds, which is considered as the most ideal way and I introduce the economic role of bonds in local governments' finance.

\subsection{Why Issuing Bonds by Local Authorities Makes Sense}

Borrowing - and specifically the issuance of bonds - represents one possible and important way to finance local capital projects. There might be several important arguments for borrowing by local governments and against other forms of financing. As Swianiewicz (2004) states, long-term debt allows sub-national governments to acquire or build capital improvements more quickly than they could on a pay-as-you-go basis. Borrowing over time is an effective way to overcome the problem of inequitable burden of costs among tax payers. It allows more equitable payment schemes, since users can be made to pay for the capital cost of facilities as they are used over time. There will be a confidence that the most users will pay for the benefits either through local taxes or directly through user charges and thereby an optimal allocation of resources can be achieved.

Petersen - Valadez (2004) agrees that benefits from accelerated local development can overshadow the cost of borrowing. Carrying out the investment as quickly as possible, operational costs (related to the given service) can be reduced. Borrowing can also stabilize the required budget resources. The volume of capital spending in local government units fluctuates from one year to another. If capital projects are financed from current revenues, the demand for resources changes over time as well. In countries where a large proportion of local revenues are raised through local taxes, an irrational fluctuation of local taxes rates may result (Kovács, 2008). 
However, there are also costs and risk of local borrowing. Agreeing with Ter-Minassian (1996) long-term debt does limit a sub-national government's future budget flexibility. Unwisely used, it can burden citizens with high taxes or service charges. As Musgrave's "Golden Rule" states, long-term borrowing can be used only for investment purposes (Musgrave, 1959). Many countries permit long-term debt only for capital spending and not for operating deficits (Dafflon, 2002). Borrowing to meet short-term financing needs can provide opportunities for banks and sub-national governments to develop working relationships and allow bankers to become familiar with the governments' financial affairs. Provided that the financing is repaid within the budget year and that carrying debt beyond the budget year is prohibited, there is no a priori reason to limit such financing to capital spending (Freire - Petersen, 2004).

\subsection{Borrow from a Bank or Issue Debt?}

Even if borrowing appears to make the most sense, the type of borrowing that is most appropriate to finance capital projects needs to be considered (Noel, 2000). The simplest way might be to borrow through a local or national bank and an alternative method would be to issue debt on either the domestic or international capital markets.

\section{Possible Advantages of Bond Financing}

In the case of bond financing sub-sovereigns can get all the funds they need up-front through the bond offering and are not subject to partial payments based on a bank's monitoring of the project construction progress. In other words the whole credit sum is available immediately so it makes the eventual reinvestment of capital possible for local governments.

Besides, domestic bond markets can provide an added source of financing that can tap into the wealth of a wide range of players, from individual investors to pension and mutual funds. The marketability of bonds induces the fact that theoretically more funds from potential investors are available for the local governments and several potential investors' savings can thereby be mobilised with the help of bonds. Another consequence of marketability that bonds generally allow longermaturity debt than bank loans and they may indeed provide a cheaper source of capital, especially, when the offering is backed up by a robust dedicated revenue source (El Daher, 1997). There are also lower prices, 
lower interest rates available because of marketability. Compared to bank loans money assets can potentially be procured at lower interest rates. Because of economies of scale, the borrower can have higher bargaining power, which can make it possible to obtain more favourable conditions.

The more flexible cash flow of the bond is also a crucial argument in favour of bonds versus bank loans. In general, in the case of bond financing the whole sum of the capital payment is due only at maturity. Therefore - in the case of necessity or intention - it is also conceivable that the repayment of the present sum of money will be financed by the financial instruments deriving from a new bond issuance and so the obligation of the repayment of the face value can be "rolled on".

The distant nature of the relationship between bondholders and issuers can enhance both the efficiency and transparency of government operations. At the same time there is an opportunity - taking advantage of strength of potential local linkages - to raise and use funds for expansion resource costs which are favourable than market conditions through public issue of bonds (Peterson, 2000).

\section{The Eventual Drawbacks of Bond Financing}

The advocates of bond's issuance, however, do not reckon with the fact that sub-sovereigns needs to work on risk management, though the conditions related to staffing, experience, and material resources required for well-founded local management are still missing in many places. (El Daher, 2004). Auditing and other transaction costs make this instrument a great deal more expensive. Moreover, issuing bonds increases the administrative costs of borrowing. The local governments have to provide more detailed information for the investors than they would in the case of bank loans.

The advocates of bond's issuance, however, do not reckon with the fact, that sub-sovereigns needs to work on necessary risk management ${ }^{1}$, though the conditions related to staffing, experience and material resources required for a well-founded local management are still missing in many places. (El Daher, 2004). Auditing and other transaction costs ${ }^{2}$ make this instrument a great deal more expansive. In addition issuing

1 Considering, e.g. interest rate and foreign exchange rate risk.

2 Procedural fee for supervision, trading cost, the fee for taking it to the stock exchange, etc. 
bonds increases the administrative costs of borrowing. The local governments have to provide more detailed information for the investors than they would in the case of bank loans. ${ }^{3}$

\subsection{Internal conditions of bond financing}

In what follows I try to determine the theoretical model of bondfinancing of local authorities. In it, three players can be identified in the procedure of local government bond issuance I refer to potential issuers of bonds, i.e. players at the sub-national level, primarily municipality-level local governments as the supply side. Demand side comprises savers and investors who are willing to purchase bonds. The model's third player is the central government. Since local governments belong to the state budgetary system and institutional investors are the most significant representatives of potential demand side, though belonging to the profitoriented competitive sector, a different approach should be used while examining both the demand and the supply side. In accordance with the foregoing, it is both logical and feasible to analyze the two sides separately.

Fig. 3: Connection System of Local Government Bond Financing Players

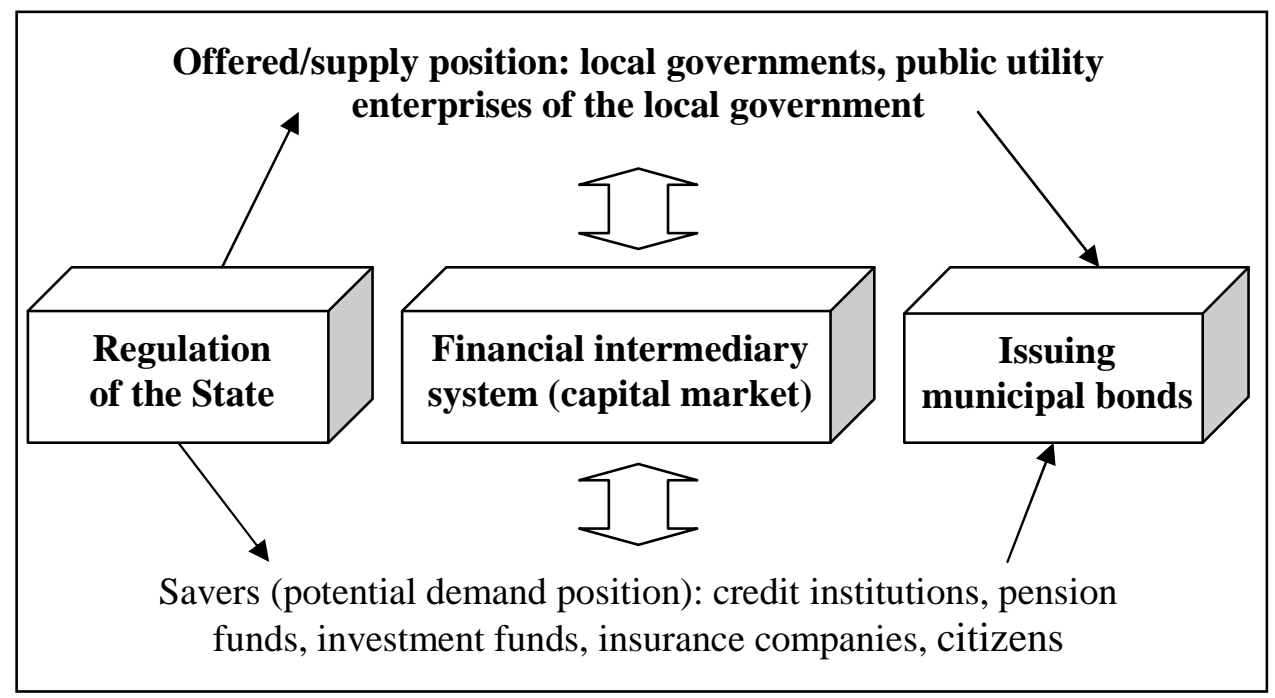

Source: Own construction

E.g. preparing a prospectus, publishing a report every year to the Supervisory Commission, and publishing Extraordinary Information where important changes occurred in the project or in the local government. 
Accordingly, the theoretical-methodological part makes up the framework for the results of the empirical surveys to be presented later. The set of research aims includes the examination of internal conditions of Hungarian bond financing at present. Under the notion "internal conditions" I mean whether potential issuers are adequately informed, professionally trained and motivated. Another aim of the research is to survey local governments' attitude towards bond financing as well, that is to determine factors not necessarily rational but sometimes subjective, which can result in impeding resource deployment through bond issuance.

\section{Research methodology}

As has been mentioned in the previous chapter, research aims include the examination of internal conditions of Hungarian municipal bond financing at present. More specifically I am going to examine whether the executives of local governments are adequately informed, professionally trained and motivated concerning financing through municipal bonds. The aim of the research is to survey local governments' attitude towards bond financing as well. The main hypothesis of the research can be formulated in the following way:

In today's Hungary the majority of local governments at the municipality level are not only short of knowledge about principles of economics relating to loan financing (including bond financing), but they are often not even aware of the positive characteristics of municipal bonds, thereby having a negative attitude to bond financing. As a consequence, the improvement of internal conditions of bond financing could not have been the main reason for the present bond boom in Hungary.

\subsection{Description of the Research}

1. The population: All the Hungarian local governments.

2. Method of sampling: The sampling method should have ensured the sample to be representative of the population concerning the size of the municipalities (number of inhabitants) and regional classification. For the measurement of population I have used an ordinal variable with 7 frequency intervals, while as a basis for identifying regional classification the official administrative regions were used. 
3. The sample: To meet the application requirements for use of statistical methods and to ensure the statistical significance of the resulting conclusions, a stratified sample of 308 local governments was selected. As the first step the sample was distributed among strata uniformly based on the regional location of the municipalities. After taking into account the distribution of the number of inhabitants in the given region, the municipalities of the study were selected by simple random sampling. ${ }^{4}$

4. Sample items: Examining a given local government as the respondent always the mayor (in case of relatively smaller municipalities) or the head of the Municipal Finance Office was interviewed.

5. Way of observation: Data were collected through personal interviews in which a standard questionnaire was filled in by an interviewer.

\subsection{The method of research}

The questionnaire being used to test the knowledge of the respondents contained statements about the most important theoretical concepts and relationships and appropriate practical use of local borrowing, including bond-financing, as well. With the questionnaires I primarily targeted testing the professional expertise of the local municipal bodies regarding the most important theoretical characteristics and relationships of loan financing, including bond financing and their appropriate uses in practice.

In order to get comparable results and facilitate responses to the questions, only a so called "passive" testing of knowledge was carried out. In other words, respondents could choose among specified options based on their perceptions. Accordingly, the respondents were asked to choose from three alternatives: in addition to the answers "true" and "false" a third alternative, "not known" was also available. In this way, knowledge or lack of it, as well as possible misconceptions, became testable and measurable. Offering a third alternative also meant that respondents did not have to guess or "give a hint" and thus were able to avoid arbitrary answers that could distort the results of the inquiry. This third alternative was communicated by the interviewer in a neutral way in order to make it easy for the respondent to acknowledge that he did not know the correct answer.

4 The reproduction of an appropriate distribution was ensured by the application of chance coefficients matching regional rates. 
Besides formulating the questions and possible answers to the questionnaire in an appropriate way, it was also vital to decide on which field of knowledge ought to be tested. Accordingly, the questionnaire contained questions testing not only professional knowledge about municipal bonds, but also knowledge about the basics on using external funds for financing. The reason for this is that bond-financing is one possible financial tool and therefore an essential part of borrowing, so it is reasonable to discuss knowledge about both fields at the same time, viewing the wider context.

In formulating the test questions, I had two priorities: firstly it was important to be able to test knowledge about the most important theoretical characteristics and interrelationships of loan- and bondfinancing. Secondly, it was essential that the appropriateness of the answers should be independent of the unique characteristics of the given municipality took part in the test. In addition to professional theoretical knowledge, the practical expertise in terms of questions of law and regulations were important as well.

\section{Results of the research}

Based on the responses to the questions the distribution of knowledgevariables became to be identified. Assessing the results, as they were pure relative frequencies of the samples, it was taken into account whether the differences based on the samples were significant or not. Carrying out the test of goodness of fit, it became clear that the distribution of each variable in knowledge was significantly different than the uniform distribution, i.e. there are discernable differences and potential tendencies in the levels of knowledge in the different areas of expertise. ${ }^{5}$ In what follows I am going to study whether there are significant differences, and explain these differences in the results related to the various knowledgevariables concerning loan finance. In that process, with the help of statistical estimation and hypothesis-testing, sample results were being extrapolated to the population i. e. to the entire local government sector of Hungary.

First, I compared the proportion of incorrect answers in case of each variable. Based on this, the following groups could be identified. The majority of wrong answers were connected globally to the field of

\footnotetext{
5 The p-value of the tests was practically equal to 0 in case of each variable.
} 
borrowing. About half of the municipalities had misconceptions concerning it. Taking out loans was judged to be inevitable but bad by the most local governments, and the municipalities were not aware of its real social and economical role; they ignored its benefits and advantages. The proportion of respondents giving wrong answers was also quite significant, including in the case of questions which tested also concrete knowledge about the issuance of bonds as a tool of fundraising through securities, and also about recent Hungarian national regulations on local borrowing as a source of funding. The proportion of local governments who had misconceptions about the possible scheduling of bonds' cashflow was between $8 \%$ and $18 \% .^{6}$ The smallest proportion of incorrect judgements by the local authorities was related to the investment-priority of borrowing and to the general fund-raising function of securities.

Examining the answers of local governments who chose the third alternative ("not known"), not as many significant differences were found among the knowledge-variables than in previous studies. The most significant ignorance of local governments was found regarding the issuance of bonds. Based on the survey it can be estimated that more than half of Hungarian local governments had no knowledge about bond financing. Fewer, but still quite number of, local governments lack knowledge about the intergenerational approach of local authorities' borrowing. The proportion of those municipalities who admitted their ignorance concerning the other two important theoretical rules of borrowing was even more significantly lower.

Finally, I examined also the distribution of correct answers by each knowledge-variable. The local governments were clear mainly about the investment purpose of long-term borrowing. Based on my estimation, about $25 \%$ to $30 \%$ of Hungarian local governments understood the possibility of sharing financial burdens of borrowing among generations, and they were aware of the function of borrowing as a municipal fundraising instrument, and they correctly judged the general fundraising function of bonds as securities. The least correct answers were made given to questions on the practical use and recent regulation of municipal bonds.

6 Interval estimation of population proportion at a level of 5\% of significance. 


\subsection{Quantifying the level of knowledge}

Since the assessment of local governments' knowledge about borrowing and bond-financing was carried out with help of multiple knowledge-variables I considered it important to identify an aggregate variable which can be measured at least on an ordinal scale so that the municipalities' level of knowledge become comparable and quantifiable. Accordingly, the respondents could score negative, zero and positive marks depending on whether their choice was correct or they chose the third option ("not known"). Local governments which made an incorrect answer received negative marks in order to emphasize the importance of misconceptions, while the total score of local authorities which opted for the third alternative was not changed. The general level of knowledge was measured as the sum of scores related to all questions.

Nonetheless, the level of knowledge can be measured in a more sophisticated way - compared to simple homogenous analyses of the answers given - if we evaluate also the differing importance of the variables and their weights and accordingly assign to them different weights when calculating a total score. For this reason, I used different weights for the variables, and gave more weight to those variables that proved to be more decisive i. e. to variables concerning knowledge which played the most important role in taking the right decision on bondfinancing. ${ }^{7}$ On the other hand I preferred to give also a larger weight to those knowledge-variables that - according to previously conceived theories - are considered the most important and essential for the sound use of local borrowing. With this method of differentiating the importance and weight of quantitative variables, it was possible for us to measure the aggregated level of knowledge for each local government with help of the aggregate knowledge variable.

7 During the identification of weights I had taken into account the findings of my deep interviews with the executives of municipalities who managed to carry out a successful municipal bond issuance and a use of bond financing judged as suitable also from academic point of view. 
In order to obtain clearer results and to be able to assess the knowledge level of all the Hungarian local authorities I created a frequency distribution with three classes. ${ }^{8}$ On the basis of the distribution we could conclude that $15 \%$ of local governments in our sample had not only no adequate information whatsoever about the most important economic relationships and characteristics of borrowing and bondfinancing, but they were even misinformed and distrustful about them and had misconceptions, and were "imprisoned" by completely false prejudices.

Tab. 1: Classification of local governments based on the level of knowledge

\begin{tabular}{|c|l|c|c|}
\hline $\begin{array}{c}\text { The value } \\
\text { of aggregate } \\
\text { knowledge } \\
\text { variable }\end{array}$ & Level of knowledge & $\begin{array}{c}\text { No. of local } \\
\text { governments } \\
\text { in the sample }\end{array}$ & $\begin{array}{c}\text { Proportion } \\
\text { of local } \\
\text { governments }\end{array}$ \\
\hline$(\mathbf{- 1 6 )}-\mathbf{( - 2 )}$ & Significant fallacies & 42 & $14.8 \%$ \\
\hline $\mathbf{( - 1 )}-\mathbf{1}$ & Lack of information & 99 & $34.8 \%$ \\
\hline $\mathbf{2}-\mathbf{1 6}$ & Significant knowledge & 143 & $50.4 \%$ \\
\hline Total & & 284 & $100.0 \%$ \\
\hline
\end{tabular}

Source: Own construction

As the distribution of the aggregate knowledge variable showed, the knowledge level of $35 \%$ of local governments could be called extremely low, that is, in basically all areas examined it hardly differed from zero. As a result only a half of the municipalities could be considered as possessing at least some significant knowledge in the fields studied.

8 Developing the class limits it was a basic principal that using a 5\% level of significance in case of local governments assigned to the middle class the value of aggregate knowledge variable shall not differ significantly from zero i.e. the expected value of the number of correct answers shall be zero 
Fig. 4: Distribution of local governments by clusters

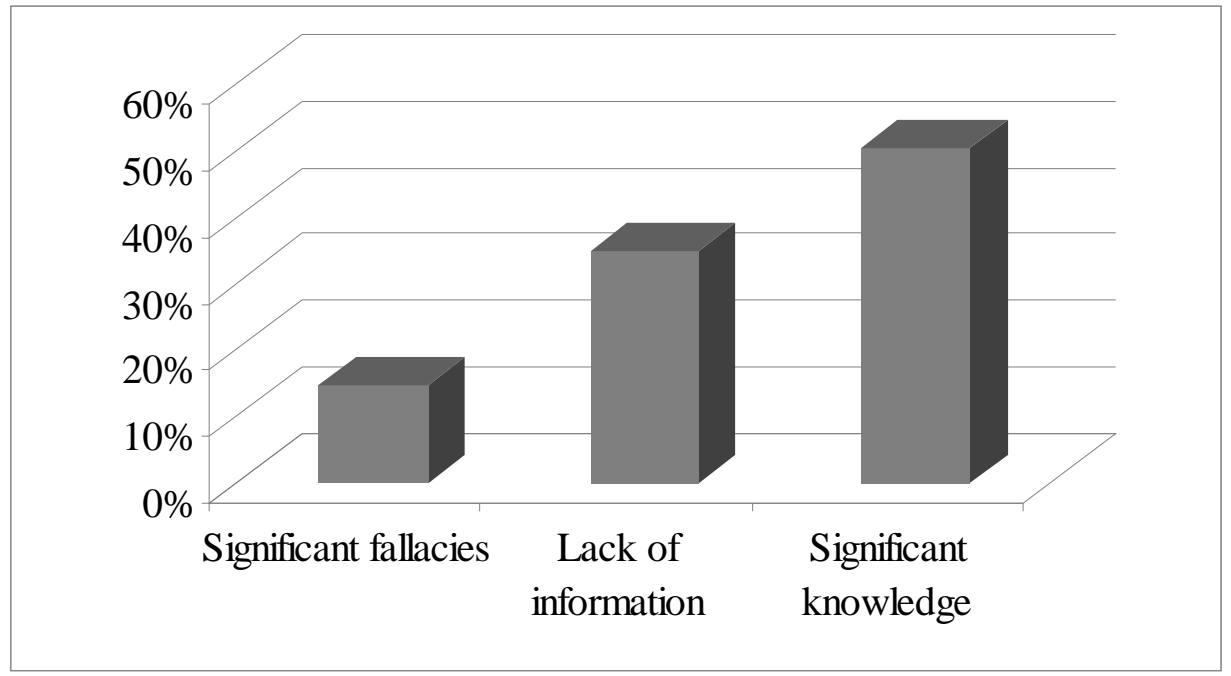

Source: Own construction

In order to understand more deeply the reasons behind the lack of knowledge I examined also whether there was a relationship between the level of knowledge and the qualitative variable showing whether the municipality has ever issued a municipal bond. Although the relationship between the variables was significant ( $\mathrm{p}$-value $=0.023$ ), the strength of the association could be considered only weak.

\subsection{Analysing knowledge-variables by means of Multivariate Statistical Analysis}

By identifying a frequency distribution with classes by means of interval estimation three clusters of local governments could be distinguished based on the general level of their knowledge. Nonetheless, it was also essential to analyse how knowledge was spread among different dimensions of the variables. After identifying the correlation matrix of knowledge-variables the question arose whether the relationship between knowledge-variables were due to the effects of underlying factors. In other words, it seemed to be important to analyse whether the level of knowledge of the municipalities could be described in terms of only a few factors instead of applying all previously used knowledge variables. Accordingly, I used factor analysis to try to construct latent variables which could account for an as largest as possible part of variability in knowledge and hereby the number of knowledge-variables 
could be reduced significantly.

Although all the knowledge-variables were measured on the same measurement scale, I analysed their standardized values in order to get a more flexible interpretation. In spite of the significant rejection of Bartlett-test's null hypothesis ${ }^{9}$ and that the Kaiser - Meyer - Olin statistics was higher than 0.5 the values of communalities indicated in advance that expectedly clearly interpretable and coherent factors can not be identified. This was also supported by the fact that the knowledgevariables examined based on the communalities contained a few dominant variables. In addition, in the case of most of the potential factor models in spite of factor rotation - problems arose in interpreting latent variables.

Since factor analysis could not meet with resounding success, I then tried to create simple patterns in the relationships among knowledgevariables by the means of principal component analysis as well. Accordingly, by using the results of previous inquiries, in a few steps I managed to identify three principal components. Furthermore, the principal components were easy to interpret, had robust characteristics, and a quite good fit to the data set.

The first principal component contained knowledge-variables of the following areas tested by the questionnaire: special characteristics of municipal bonds' cash flows (e.g. flexibility, repayment due at maturity), the possibility of raising local citizens' funds, and the general fundraising role of securities. Based on the component matrix all the variables had strong contribution to the variance of the principle component. On the grounds of the selected knowledge variables this first principal component can be interpreted as an aggregate knowledge variable of local governments about municipals bonds as a fundraising financial instrument issued on capital markets. Based on the component matrix we can conclude that all the variables had strong contribution to the variance of the principle component. The strongest influence was shown by variables regarding the bonds' cash flows. The first principal component could account for about $60 \%$ of variability in the data set.

The second principal component of the model was constituted by knowledge-variables that contained questions related to the intergenerational approach of local governments' borrowing and the

\footnotetext{
9 The null hypothesis could have been rejected at any level of significance.
} 
investment-priority of long-term fundraising, as well as the general role of borrowing in local finance. Based on knowledge-variables included in the second principal component, it could be interpreted as an appropriate measure for local authorities' knowledge about the most important theoretical rules of local borrowing. The second principal component could explain approximately a further $30 \%$ of heterogeneity in the data set. The third and last principal component included only one dominant variable which tested knowledge concerning the rules of public procurement in local governments' borrowing. Accordingly, it could be labelled as an aggregate variable measuring the general level of knowledge about legal and administrative tasks related to local borrowing.

Tab. 2: Dominant variables of principal components

\begin{tabular}{|l|l|}
\hline Dominant knowledge-variables & Principal components \\
\hline $\begin{array}{l}\text { Flexible cash-flow of bonds } \\
\text { Raising local citizens' funds } \\
\text { Repayment due at maturity } \\
\text { Collecting the savings of several market players }\end{array}$ & $\begin{array}{c}\text { I. Securities issued } \\
\text { on the capital market }\end{array}$ \\
\hline $\begin{array}{l}\text { Role of borrowing in local finance } \\
\text { Intergenerational approach of borrowing }\end{array}$ & $\begin{array}{l}\text { II. Theoretical knowledge } \\
\text { of local borrowing }\end{array}$ \\
\hline Rules of public procurement & $\begin{array}{c}\text { III. Legal and adminis- } \\
\text { trative regulation } \\
\text { of public sector }\end{array}$ \\
\hline
\end{tabular}

Source: Own construction

Summarizing the results of principal component analysis it can be stated that local governments' level of knowledge are significantly captured with the help of three principal components. The first one measures knowledge about how securities (municipal bonds) can be issued and traded on the capital markets; the second one tests the knowledge about theoretical rules of local borrowing, while the third component emphasizes the importance of the administrative and legal approaches in bond financing.

Nonetheless, the statistical model constructed by the means of principal component analysis can be considered as adequate only in the 
case in which the three components taken together give a significant explanation for the different levels of knowledge of local governments. In order to test it a regression model was identified where the three principal components as independent variables were being used. The regression equation formulated proved to be significant at all significance levels and the regression model explained almost two-thirds of variability in the aggregate knowledge variable. Accordingly, regression analysis confirmed that the level of knowledge of local authorities can actually be separated and explained based on dimensions created by the three principal components.

\section{Conclusion: Did external factors dominate?}

Sample results and their statistical extrapolation to the entire Hungarian local government sector confirmed that the level of knowledge of municipal executives about local borrowing and, within that, about bondfinancing, can be considered extremely low.. It also means that internal factors couldn't have been the accelerator of the process using this form of fundraising, considered in Hungary still to be quite innovative. Accordingly, it can be stated that instead of internal factors, external ones played the dominant role. Although a complete analysis of external variables that have a significant effect on the bond boom is beyond the scope of this study, in what follows, in order to receive a full panoramic view of the situation, I attempted to analyse briefly some external factors that were considered to be dominant. (See in more details: Kovács, 2011.)

The wave of debt which started at the end of 2006 can be traced back the joint effect of various external factors. The government's bill restraining local governments' borrowing and the fear of restrictions were of primary importance among effective causes. ${ }^{10}$ The intent to counteract the stresses originated from the resource oriented system also had an effect on borrowing proclivity but it could not be only reason for bond boom. At the same time - see figure 4 - the GFS deficit situation is clearly not the only reason for debt. No firm correlation could be established between the deficit and the development of outstanding total debt in the years studied. In addition, the accelerated increase in debt cannot be attributed to the increasingly absorbent quality of EU funds either.

${ }^{10}$ Bill No. T/4320. for the modification of Act No. LXV of 1990, $9^{\text {th }}$ November 2007. 


\section{Fig. 5: The GFS balance of municipalities and the formation of outstanding total debt between 2002 and 2008 (in billion of HUF)}

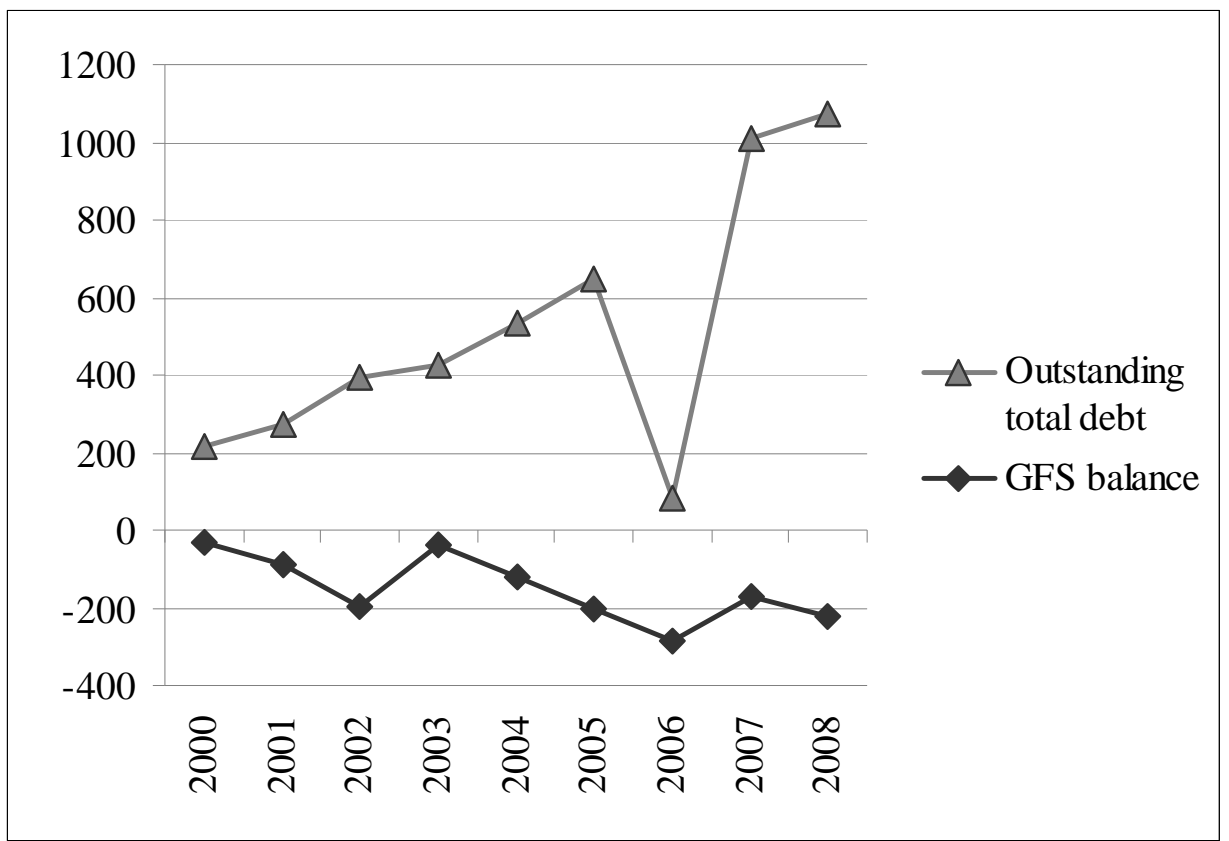

Source: Own construction

Examining external factors, we can conclude that the characteristics of Hungarian regulation of local borrowing have also probably contributed to the spread of municipal bonds. Amending the Act on Local SelfGovernment (1990/LXV) legal restrictions came into force after the first bond-boom in 1996. According to these, municipalities are not permitted to meet their debt service obligations from Personal Income Tax Revenues, Normative State Contribution, Central Subsidies or sales of Core Assets and total debt ${ }^{11}$ cannot exceed the Corrected Current Own Revenues, which is 70 per cent of the positive difference between Current Own Revenue and Short Term Liabilities. Nonetheless, regulation though unintentionally - left a loophole: the debt limit doesn't apply to liquid loans.

Another characteristic of the national regulations is that the Public Procurement Act does not order obligatory public procurement procedures during issue contrary to the case of borrowing. Consequently,

${ }^{11}$ Bank loans, municipal bonds, lease, third-party obligations and commitments. 
Kovács, G: Municipal Bond Boom in Hungary: Focusing on the Analysis of Local Financial Management.

central regulation encourages the issuance of bonds over borrowing from banks, as increased administration costs and responsibilities of public procurement can be saved by bond-issuing local governments.

\section{References}

[1] Dafflon, B. (2002): The Requirement of a Balanced Budget and Borrowing Limits in Local Public Finance: Setting Out the Problems. In: Dafflon, B. (ed.): Local Public Finance in Europe: Balancing the Budget and Controlling Debt. Cheltenham-Northampton, Edward Elgar, 2002, pp. 1-13.

[2] El Daher, S. (1997): Municipal Bond Markets. Washington D. C., World Bank Infrastructure Notes, No. FM-8a, 1997.

[3] El Daher, S. (2004): Credit Markets and the Role of Specialized Intermediaries in Local Infrastrucure Finance. In: Kopányi, M.Wetzel, D. - El Daher, S. (eds.): Intergovernmental Finance in Hungary. A Decade of Experience 1990-2000. Budapest, LGI, 2004, pp. 527-546.

[4] Freire, M. E. - Petersen, J. (2004): Political, Legal and Financial Framework. In: Freire, M. - Peteresen, J. (eds.): Subnational Capital Markets in Developing Countries. New York, Oxford University Press / World Bank, 2004.

[5] Hungarian National Bank (2011): Statistical Time Series. [on-line], Budapest, Hungarian National Bank, c2011, [cit 31 ${ }^{\text {st }}$ May, 2011], $<$ http://english.mnb.hu/Statisztika/data-and-information/mnben_stati sztikai_idosorok>.

[6] Kovács, G. (2008): Financing Local Governments' Investments in Hungary by Issuing Municipal Bonds: Experiences and Future Prospects. In: Vass, L. - Kulenkova-Orzhel, O. - Pollitt, C. (eds): Leadership and Management in the Public Sector: Values, Standards and Competencies in Central and Eastern Europe. Bratislava, LGI/OSI, 2008, pp. 119-131.

[7] Kovács, G. (2011): Municipal Bond Market in Hungary: Constrains and Chances. In: Ryder, A. - Bucek, J. (eds.): Governance in Transition. Portsmouth, Springer, 2011 (in print)

[8] Musgrave, R. (1959): The Theory of Public Finance. New York, McGraw-Hill, 1959. 
[9] Noel, M. (2000): Building Subnational Debt Markets in Developing and Transition Economies. Washington D. C., World Bank Policy Research Working paper 2339, 2000.

[10] Petersen, J. - Valadez, M. (2004): Borrowing Instruments and Restrictions on Their Use. In: Freire, M. E. - Petersen, J. (eds.): Subnational Capital Markets in Developing Countries. New York, Oxford University Press / World Bank, 2004.

[11] Peterson, G. E. (2000): Building Local Credit Systems. Washington D. C., World Bank, Municipal finance Background Series 3, 2002.

[12] Swianiewicz, P. (2004): The Theory of Local Borrowing and the West-European Experience in Local Government Borrowing. In: Swianiewicz, P. (ed.): Risk and Rewards. Budapest, Open Society Institute, 2004.

[13] Ter-Minassian, T. (1996): Borrowing by Subnational Governments: Issues and Selected International Experience. Washington D. C., International Monetary Fund Paper on Policy Analysis Assessment 96/4, 1996. 


\title{
Municipal Bond Boom in Hungary: Focusing on the Analysis of Local Financial Management
}

\author{
Gábor KOVÁCS
}

\begin{abstract}
The drastic increase in volume of local government debt in Hungary started in 2006. My hypothesis assumes that a supposable improvement in local municipal financial management might resulted in the spread of bond issue, which in Hungary is still considered innovative. The paper is aimed at examining factors that might have been behind indebtedness, and tries to separate the effect of internal and external factors. Under the notion "internal factors" I mean whether potential issuers are adequately informed, professionally trained and motivated. Another aim of the research is to survey local governments' attitude towards bond financing as well, that is to determine factors not necessarily rational but sometimes subjective, which can result in impeding resource deployment through bond issuance. My research, which was based on a stratified sample of 308 Hungarian municipalities, came to the conclusion that expertise of local governments' financial executives related to loan financing is extremely low. The majority of local governments is unable to distinguish the economic differences between bank loans and bonds, and is unclear concerning the potential benefits, advantages, and disadvantages of bonds. No wonder that nearly all the bonds were issued privately where the buyers were solely commercial banks. In addition, $12-18 \%$ of the municipalities has prejudices and clearly has misconceptions about obtaining funds through borrowing. According to the principal component analysis local governments' knowledge level can be classified and explained by three components: theoretical knowledge of local borrowing, knowledge of legal and administrative regulation, and skill in capital market financing. By summing up the results it can be stated that the improvement in local financial management couldn't have been the primary reason for municipal bond boom, but there were external factors that determined and dominated this process of booming.
\end{abstract}

Key words: Local governments; Borrowing; Municipal bonds; Financial management.

JEL classification: $\mathrm{H} 72, \mathrm{H} 74$. 